\section{Additional support for FRPAA}

In April, more than 350 librarians and library supporters convened in Washington, D.C., to attend the ALA's National Library Legislative Day (NLLD). Representing all types of libraries, the participants spent a day talking with members of Congress and their staff to advocate for librarians on key legislative issues. Likely not a coincidence is the fact that in the weeks immediately following NLLD, a key legislative issue for libraries and the public - the Federal Public Research Access Act of 2012 (FRPAA) (S. 2096/H.R. 4004)_-gained additional cosponsors in both the U.S. Senate and the U.S. House of Representatives.

In the Senate, Sen. Patty Murray (D-WA) joined cosponsors Sens. John Cornyn (RTX), Ron Wyden (D-OR), and Kay Bailey Hutchison (R-TX) in support of the bill. In the House, bill sponsor Rep. Michael Doyle (D-PA) garnered additional support from four more colleagues, including Reps. Suzanne Bonamici (D-OR), Peter DeFazio (D-OR), Michael Fitzpatrick (R-PA), and Cory Gardner (R-CO), bringing the total number of House cosponsors to 31.

As you may recall from the March 2012 Washington Hotline, the bipartisan supported legislation is aimed at improving access to federally (i.e., taxpayer) funded research by building upon the success of the National Institutes of Health (NIH) Public Access Policy implemented in 2008. FRPAA legislation would expand the amount of research made available and improve access by making it accessible no later than six months after publication. The growing support of FRPAA by Congress is a positive step in improving equitable access to information, and ALA will continue to strongly advocate for its passage.

Corey Williams is assistant director, ALA Office of Government Relations, e-mail: cwilliams@alawash.org

\section{ALA Washington Office programs at ALA Annual Conference}

The ALA Washington Office (WO) will offer a number of programs of interest to ACRL members at the 2012 ALA Annual Conference being held in Anaheim, California, June 21-26, 2012. WO programs include the traditional Saturday morning update on legislative, regulatory, and policy issues of the day and also a panel discussion on digital literacy and libraries and designing what comes next. In addition, the WO will host two panels on copyright. The first panel will discuss fair use and academic and research libraries and using best practices to make better practice. The second copyright panel is titled "Truth, Lies and Silly Putty: The Ties that Bind Copyright," and will explore significant policy developments that negatively affect balanced copyright law. For more program details including date, time, and location, along with information on additional WO programs, please see www.districtdispatch.org/annual2012/. General information about the ALA Annual Conference is available at www.alaannual.org/.

\section{Of note... Orphan Works and Mass Digitization symposium held}

The Berkeley Center for Law and Technology held a two-day symposium on "Orphan Works and Mass Digitization: Obstacles and Opportunities" in April. At the heart of the panel presentations and robust conversations were the possible public policy implications of legislative and other solutions to the orphan works problem. (Remember, those are the works in which the copyright holder cannot be identified or located). Fortunately for those who were unable to attend the presentations, audio files have been made available at www. law.berkeley.edu/orphanworks.htm. In addition, Carrie Russell, from the WO's Office of Information Technology Policy reflected on the conference in a recent ALA WO District Dispatch available at www.districtdispatch.org/2012/04 /and-the-food-was-good/. $\boldsymbol{n}$ 